\title{
The Effectiveness Test of Piper Betle Leaf Ethanol Extract Cream (Piper Betle Linn) Toward Propionibacterium Acnes Bacterial Growth
}

\author{
Resva Meinisasti $^{1 \#}$, Zamharira Muslim ${ }^{1}$, Krisyanella $^{1}$, Raden Sunita ${ }^{1}$ \\ ${ }^{1}$ Health Ministry Polytechnic of Bengkulu, Bengkulu, Indonesia \\ \#Corresponding author E-mail: resvameinisasti@gmail.com
}

Received : January $18^{\text {th }} 2020$

Accepted : March 25 2020

\begin{abstract}
Background

One of skin diseases that is frequently taking attention among teenagers and young adults is acne or in medical term called acne vulgaris. Acne treatment can be treated by repairing follicular abnormalities, decreasing sebum production, decreasing the number of Propionibacterium acnes colonies and reducing inflammation of the skin. The bacterial population of Propionibacterium acnes can be reduced by giving an antibacterial substance such as erythromycin, clindamycin and benzoyl peroxide. In the treatment of acne we can get antibacterial originating from nature, one of which can be obtained in the secondary metabolism of plants. The extracts and essential oils of Piper Betle Leaf contain antibacterial and antifungal activities. The effectiveness of the use of Piper Betle Leaf ethanol extract (Piper betle Linn) in acne treatment can be improved by creating formulations in form of cream preparations. Formulations in cream preparations will affect the amount and speed of active substances that can be absorbed.
\end{abstract}

Methods

The study used experimental research. Propionibacterium acnes samples were diluted in $0.9 \%$ physiological $\mathrm{NaCl}$ sterile and embedded in Nutrient Agar (NA) media. The media was inserted into an incubator at $37^{\circ} \mathrm{C}$ for 24 hours. The test of antibacterial activity used the disk diffusion method. The antibacterial activity test results were statistically analyzed using the Statistical Product Services Solution (SPSS 17) program with a confidence level of $95 \%(\alpha=0.05)$.

Results

The three creams containing Piper Betle Leaf ethanol extracts at percentages of 5\%,10\% and $15 \%$ for each had inhibitory zones: $9.8 \mathrm{~mm}, 15.85 \mathrm{~mm}, 17.35 \mathrm{~mm}$.

Conclusion

Cream that contains $15 \%$ active substance has the strongest inhibition.

Keywords: Antibacterial, Piper betle Linn, Extract, Propionibacterium acnes. 
ISSN 25980580

\section{Introduction}

One of skin diseases that is always taking attention among teenagers and young adults is acne or in medical term called acne vulgaris. ${ }^{1}$ This disease is not fatal, but rather alarming as it is associated with decreased self-confidence due to reduce of beauty on patients' faces. ${ }^{2}$ The acne is caused by many factors including: genetic, endocrine, food, activity of the sebaceous glands, psychological factors, season, bacterial infection (Propionibacterium acnes), cosmetics and other chemicals. ${ }^{1}$ Patients usually complain about skin eruptions at predilection sites, can be on the face, shoulders, neck, chest, upper back, and upper arms. In addition, acne causes discomfort, because it is accompanied by itching. Acne causes skin eruptions such as blackheads, papules, pustules, nodes, or cysts. ${ }^{3}$

Acnes can be treated by repairing follicular abnormalities, decreasing sebum production, decreasing the number of Propionibacterium acnes colonies and reducing inflammation of the skin. The population of Propionibacterium acnes can be reduced by giving an antibacterial substance for instance erythromycin, clindamycin and benzoyl peroxide. ${ }^{4}$

In treating the acne, antibacterial originating can be obtained from nature, one of which is in the secondary metabolism of plants. According to a research by Chakraborty and Shah ${ }^{5}$ which states that Piper Betle Leaf can be used as an anti-acne drug, because it has activity as an antibacterial, antioxidant and antihemolytic. Besides, Piper Betle Leaf also has antiinflammatory, anti-diabetes and radioprotective activity. ${ }^{6}$ The extracts and essential oils of Piper Betle Leaf have antibacterial and antifungal activities. From the research by $\mathrm{Fadila}^{7}$, it is suggested that the ethanolic extract of Piper Betle Leaf (Piper betle Linn.) has antibacterial activity against Propionibacterium acnes that causes acne with KBM (Minimum Kill Rate) of $0.25 \%$.

In the use of ethanolic extracts of Piper Betle Leaf (Piper betle Linn) for acne treatment can be formulated in cream preparations. The formulation will affect the amount and rapidity of active substances that can be absorbed. The active substance in the preparation of the cream enters the base or carrier which will bring the drug to contact with the skin surface. Carriers used for topical preparations will have a huge effect on drug absorption and own a beneficial effect if chosen correctly. Ideally, the base and carrier must be easily applied to the skin, are not irritating and are comfortable to use on the skin. ${ }^{8}$ 
ISSN 25980580

A research conducted by Sukriani Kursia entitled Antibacterial Activity of Ethyl Acetate Extract of Green Piper Betle Leaf (Piper betle Linn) on Staphylococcus epidermidis Bacteria, with the results of the study showed that ethyl acetate extract had antibacterial activity against Staphylococcus epidermidis in the moderate-strong category. In previous studies, the authors have formulated the Piper Betle Leaf ethanol extract cream and there are three formulas on the basis of oil in water which tested the cream to be good. Based on the result, researchers are therefore interested in testing the effectiveness of cream preparations that contains Piper Betle Leaf ethanol extract on Propionibacterium acnes bacteria.

\section{Methods}

The conducted research was an experimental laboratory which was divided into four stages, namely the manufacture of extracts, cream formulation, and Piper Betle Leaf ethanol extract cream effectiveness test.

Piper Betle Leaf were washed clean by using water to remove impurities, then drained on the board. The piper Betle was weighed as wet weight and then dried until dry simplicia. The dried leaf was crushed and blended, then weighed as dry weight. Piper Betle Leaf powder as much as $1.2 \mathrm{~kg}$ macerated with 20 liters of liquid dancers in $90 \%$ ethanol. Extract of Piper Betle was made cream formulation by add the basis cream, and got the cream formulation 5\% (FI), 10\% (FII) and 15\% (FIII).

Pure Propionibacterium acnes Pure taken one ose then scratch on the agar Nutrient agar To incubate at a temperature of $36^{\circ} \mathrm{C}$ for 24 hours. Take 2 ose from the rejuvenation in Nutrient Agar then add $2 \mathrm{ml}$ of physiological $\mathrm{NaCl}$. Rub the osenya then homogenize in the vortex mixer until the color becomes cloudy. Then take $1 \mathrm{ml}$ then drop it on petri dish that already exist Mueller Hinton media. Flatten with sterile cotton and wait for 15 minutes. Place the existing disc of the test substance and then incubate for 24 hours with a temperature of $36^{\circ} \mathrm{C}$.

The antibacterial activity test of cream of ethanol extract of Piper Betle Leaf done by disc diffusion method. The disc paper is immersed in FI, FII, FIII cream, positive control and negative control for 5 minutes and dried in the oven for 10 minutes at 45 . The disc paper is then placed on the surface of bacteria inoculated medium. Petri was left at room temperature for 1 hour before incubation at $37^{\circ} \mathrm{C}$ for 24 hours. Antibacterial activity is determined by 
ISSN 25980580

measuring the inhibitory zone diameter. For positive controls used clindamycin. Testing is done 5 repetitions.

\section{Results}

The results of the extraction were 1.2 kilograms of dried Piper Betle Leaf by maceration using $96 \%$ alcohol that obtained 102 grams of jerking extract. The inhibitory zones of Piper Betle Leaf ethanol extract were shown in table 1.

Table 1. The Inhibitory Zones Result of Piper Betle Leaf Ethanol Extract Cream

\begin{tabular}{ccccccc}
\hline \multirow{2}{*}{ Concentration } & \multicolumn{5}{c}{ Repetition } & \multirow{2}{*}{ Average $(\mathrm{mm})$} \\
\cline { 2 - 5 } & $1(\mathrm{~mm})$ & $2(\mathrm{~mm})$ & $3(\mathrm{~mm})$ & $4(\mathrm{~mm})$ & $5(\mathrm{~mm})$ & \\
\hline $5 \%$ & 6,5 & 11,25 & 10 & 10,5 & 10,75 & 9,8 \\
$10 \%$ & 17,25 & 16,25 & 15 & 15,75 & 15 & 15,85 \\
$15 \%$ & 15 & 15,75 & 15 & 23,5 & 17,5 & 17,35 \\
Positive Control & 16,5 & 22,5 & 17 & 15 & 17,75 & 17,75 \\
Negative Control & 0 & 0 & 0 & 0 & 0 & 0 \\
\hline
\end{tabular}

\section{Discussion}

The inhibition zone results found in the cream with the active ingredient of ethanol extract of green Piper Betle Leaf is the formation of a clear zone in the medium of Propinibacterium acnes bacterial growth in the extract concentrations treatment from 5\%,10\% and $15 \%$ resulting in an average inhibition zone of $9.8 \mathrm{~mm}, 15.85 \mathrm{~mm}$, and $17.35 \mathrm{~mm}$. According to David Stout, the extract concentration of 5\% falls into medium category, the concentration of ethanol extract $10 \%$ and $15 \%$ are categorized strong category. It can be seen that this is directly proportional between the active ingredient of Piper Betle Leaf ethanol extract and the inhibition zone diameter. The higher the active ingredient of Piper Betle Leaf ethanol extract in cream sedans, the greater inhibition zone toward the growth of Propinibacterium acnes.

According to a research conducted by Sri Nadya Sanin, the zone of inhibition formed shows that any concentration of Piper Betle Leaf extract can inhibit the growth of bacteria both Streptococcus mutans and Staphylococcus aureus. Overall, the average diameter of the 
inhibition zone increases with the increase on the concentration of the extract given. This is in line with the results of research that I have conducted.

The antibacterial activity of the cream comes from the activity of the active compound found in Piper Betle Leaf ethanol extract. In the active compounds of Piper Betle Leaf which are suspected to have anti-bacterial activity are flavonoids, tannins, saponins and phenols. ${ }^{9}$ Tannins have an antibacterial power through reaction with cell membranes where tannins attack cell wall polypeptides so that the formation of cell walls becomes imperfect causing lysis bacterial cells due to osmotic pressure so that bacterial cells will die, enzyme inactivation and inactivation of genetic material function where tannins inhibit the reverse transcriptase enzyme and topoisomerase DNA thus causing bacterial cells that cannot be formed. ${ }^{10}$

The increase on diameter of the bacterial growth inhibition zone in the form of cream preparations is suspected from the increased penetration of antibacterial compounds that diffuse into the test medium so that it produces a larger diameter of the bacterial growth inhibition zone. The cell wall structure of a bacterium can determine the penetration, ligament, and activity of antibacterial compounds. ${ }^{11}$ Propinibacterium acnes is a gram positive bacterium which has s a wall structure cell with more peptidoglycan, less lipids and cell walls containing polysaccharides (theatric acid). Teichoic acid is a water-soluble polymer, which functions as a positive ion transport to get in or out. The water solubility characteristic shows that the cell wall of Gram positive bacteria is more polar. High water content in cream preparations is thought to improve its polarity so that it is easier to penetrate polar peptidoglycan layers than nonpolar lipid layers. Besides, the increased effectiveness of the antibacterial extract of methanol extract of henna leaf water in the form of cream preparations can also be influenced by the carrier or base used. This study used stearic acid and triethanolamine which both are emulsifying agents that can role as surfactants. ${ }^{12}$

Based on the results of inhibition zone cream for ethanol extracts of betel leaves, the positive control used was Clindamycin having an inhibition diameter of 17.75 in strong category. As can be seen from the table, the Piper Betle Leaf ethanol extract in cream with a concentration of $15 \%$ has almost the same inhibitory power as clindamycin. Therefore, Piper Betle Leaf ethanol extract cream can be used for the treatment of acne. This is in line with the 
research of Sukriani Kursia, et al entitled Antibacterial Activity Test of Ethylacetate Extract of Green Betel Leaves (Piper betle Linn) Toward Staphylococcus epidermidis Bacteria. ${ }^{13}$

The study also included the measurement of inhibition zone of the ethanol extracts of green Piper Betle Leaf on the Propinibacterium acnes bacterial growth medium in the treatment of extract concentrations of 5\%,10\% and $15 \%$ which produced an average inhibition zone of $16.4 \mathrm{~mm}, 20 \mathrm{~mm}, 21.6 \mathrm{~mm}$. The concentration of $5 \%$ and $10 \%$ belongs to strong category and the concentration of $15 \%$ can be categorized into very strong and directly proportional between the active substance content of Piper Betle Leaf ethanol extract with the diameter of the inhibition zone. The higher percentage of Piper Betle Leaf ethanol extract, the greater the zones inhibit the growth of Propinibacterium acnes bacteria. Based on the table of inhibition zone of Piper Betle Leaf ethanol extract, the positive control used was Clindamycin having a inhibition diameter of 21.8 in very strong category. As can be seen on the table, the Piper Betle Leaf ethanol extract with a concentration of $15 \%$ has almost the same inhibitory power as clindamycin. When compared to the results of inhibition zones between creams containing Piper Betle Leaf ethanol extract and Piper Betle Leaf ethanol extracts, there is a difference, where in the ethanol extracts of betel leaves that have been used as creams have reduced inhibitory power. It is caused by the extract in the cream still has to release the carrier base before penetrating to the skin. Formulations in cream preparations will affect the amount and rapidity of active substances that can be absorbed. Carriers used for topical preparations will have a huge effect on drug absorption and have a beneficial effect if chosen correctly. Ideally, the base and carrier must be easily applied to the skin, are not irritating and are comfortable to use on the skin. ${ }^{6}$

In this study, the antibacterial activity of green Piper Betle Leaf which contains efficacious compounds with the main component of the bioactive substance is kavikol which is also the content of essential oils. Essential oils consist of phenols and derivatives such as estragol, eugenol, carvacrol, and sesquiterpenes.

These compounds have certain charateristics, so that the Piper Betle Leaf can be a medicine that can cure various diseases. Eugenol has antiseptic, analgesic, and antiinflammatory characteristics that accelerate the wound healing process. Estragol has antibacterial characteristic, especially toward Shigella sp. Also, monoterpenes and 
sesquiterpenes have the same characteristic as eugenol. Carvacrol is as a disinfectant and antifungal so it can be used as an anti-septic.

\section{Conclusion}

It can be concluded that out of the three creams containing Piper Betle Leaf ethanol extracts on a percentage of 5\%,10\% and 15\%, each has inhibitory zones: $9.8 \mathrm{~mm}, 15.85 \mathrm{~mm}$, $17.35 \mathrm{~mm}$. Cream with $15 \%$ active ingredient has the strongest inhibition.

\section{References}

1. Yuindartanto, A., 2009. Acne Vulgaris. Fakultas Kedokteran Universitas Indonesia

2. Efendi, Z., 2003. Peranan Kulit dalam Mengatasi Terjadinya Akne Vulgaris

3. Harper, J.C., 2008. Acne Vulgaris. Department of Dermatology, University of Alabama at Birmingham.

4. Eshtiaghi \& Kuldiloke. 2013. Formulation Of Anti Acne Cream Containing Natural Antimicrobial. International Research Journal Of Pharmacy,4 (11)

5. Chakraborty \& Shah. 2011. Antimicrobial, Antioxidative And Antihemolytic Activity Of Piper Betel Leaf Extracts. International Journal of Pharmacy and Pharmaceutical Sciences, Vol 3 Suppl 3

6. Arambewela, R. and J. Hall, 2009. An empirical model of international student satisfaction. Asia Pacific Journal of Marketing and Logistics, 21(4): p. 555-569.

7. Zenda F.P. 2010. Uji Aktivitas Ekstrak Etanol Daun Sirih (Piper betle L.) Terhadap Propionibacterium acne dan Staphylococus aureus Multiresisten. Univ.Muhamadiyah Surakarta.http://v2.eprints.ums.ac.id/archive/et d/10092/65-67.

8. Wyatt, et al., 2003. Oxford Handbook of Accident and Emergency Medicine. Hypertensive Crises. New York : Oxford University Press

9. Mun'im A, E Hanani dan Rahmadiah. 2009. Karakterisasi Ekstrak Etanolik Daun Asam Jawa (Tamarindus indicaL.). Majalah Ilmu Kefarmasian VI(1):38-44

10. Nuria, maulita , Faizaitun, Arvin dan Sumantri. 2009. Uji Aktivitas Antibakteri Ekstrak Etanol Daun Jarak Pagar (Jatropha Curcas L) Terhadap Bakteri Staphylococcus aureus Atcc 25923, Escherichia coli Atcc 25922, Dan Salmonella typhi ATCC 1408. Mediagro 
$5(2): 26-37$.

ISSN 25980580

11. Jawetz E., Melnick JL., Adelberg EA., Brooks GF., Butel JS, Ornston LN. 2001. Mikrobiologi Kedokteran. Terjemahan E. Nugroho dan RF. Maulany. ed ke-20. Jakarta: EGC. pp 211-217.

12. Kuswahyuning R., Saifullah. 2008. Teknologi dan Formulasi Sediaan Semipadat. Yogyakarta: Laboratorium Teknologi Farmasi Fakultas Farmasi UGM.

13. Sukriani Kursia, Juliandri S, Burhanudin Teabe, Asril Burhan,Wa OR Rahim, Nursamsiar. 2016 Antibacterial Activity Test of Ethylacetate Extract of Green Betel Leaf (Piper betle L.) towards Staphylococcus epidermidis Bacteria. IJPST Vol 3 No 2 